\title{
Adaptation of Communication to Community-Based Tourism Towards Tourism 4.0
}

\author{
Bernadette Dian Nugraheni ${ }^{1}$, Andre Rahmanto ${ }^{2}$, Ismi Dwi Astuti Nurhaeni ${ }^{3}$ \\ Department of Communication, Faculty of Social and Political Science, Universitas Sebelas \\ Maret, Surakarta, Indonesia ${ }^{1,2,3}$ \\ \{bernadettediannugraheni@student.uns.ac.id ${ }^{1}$, andre@staff.uns.ac.id ${ }^{2}$, ismidwiastuti@staff.uns.ac.id $\left.{ }^{3}\right\}$
}

\begin{abstract}
In 2018, the Ministry of Tourism of the Republic of Indonesia stated that $70 \%$ of tourists both foreign and domestic tourists use digital media for booking and selling tourist trips; tourists who make online purchases by $51 \%$ are carried out by millennials. This condition reflects that Indonesia's tourism is ready for tourism 4.0. Thus, the Ministry of Tourism emphasizes the development of human resources to accelerate digital lifestyles. Therefore, Community Based Tourism (CBT), as a human resource at the local level, sustainable, needs to develop themselves through innovation and collaboration. This study aims to examine the structuration process of collaboration and CBT innovation during tourism digitalization. This study uses a qualitative method. Data was collected from the literature review of the last 5 years, observations and interviews to be able to see the initial communication structure and subsequent structural changes which allow and limit the innovations made by CBT. The informants selected and in accordance with the research were managers of the Tourism Skyline Village, Mangunan, Bantul, Yogyakarta Special Region Province. The results can be stated that in the management system of CBT, agents appropriate resources and rules, which were originally produced and then reproduced for deliberate adaptation through actions and interactions to achieve goals. The structure that is formed and precisely can help complete the goals of collaboration and bring about a continuous diffusion of innovation. Collaboration and innovation of CBT through cooperation in the promotion and development of tourism products with the government, Generasi Pesona Indonesia (Gen-PI), and academics is more done especially during tourism 4.0.
\end{abstract}

Keywords: Adaptive Structuration Theory; Collaboration; Innovation; Community Based Tourism; Tourism 4.0

\section{Introduction}

The development of community based tourism has been recognized as a sustainable tourism development. The tourism climate is created as a manifestation of the dynamics of the community so it needs to be seen the potential of each region. Sustainability in tourism is seen in community involvement. The involvement of the general public encourages the 
preservation of nature and culture as tourism products. Communities contribute from planning to evaluation to develop their area. While tourism development plans are often realized not entirely because of the influence of the volatile tourism industry on the tourism climate [1].

Changes in the tourism industry or business to the situation and conditions must be balanced with the right strategy so that it will soon be stable and developing. Especially during the 4.0 industrial revolution, the Ministry of Tourism of Republic of Indonesia encouraged all tourism actors to tourism digitalization. However, success in implementing tourism digitalization or going digital requires collaboration with various parties both industry, entrepreneurs, central government, local governments and community organizations. The Indonesian government is catching up with the industrial revolution when compared to Japan, which entered society 5.0. The difference between industry 4.0 and society 5.0 lies in the point of view and perspective. Industry 4.0 implements technology in technology development while Society 5.0 uses a more human-focused approach [2], [3]. Industrial Revolution 4.0 and Society 5.0 continuously solve every problem and challenge contained in it with a combination of innovations from various elements implemented in the industrial revolution 4.0 and integrated with society 5.0 [4].

The 4.0 industrial revolution has an impact and is transforming the mode of production and the work of the people. Industry 4.0 combines industrial models that adopt the characteristic features of digital culture with automitation. Mazali (2017) argues that the ideal type of industrial 4.0 workers is participatory and proactive unlike the resistant or reactive workers of the twentieth century. Proactive position and participatory messages in accordance with the process of division of responsibilities given [5]. Likewise Industry 4.0 played a role in the appearance of Tourism 4.0. In Tourism 4.0 the availability of big data on tourist behavior collected through apps and sensors. Then the big data collection is processed to create a seamless and personalized traveling experience [[6]. The key to the grand strategy of tourism 4.0 is human resources [7]. Human resources owned by the tourism industry and tourism businesses are required to develop their abilities.

Community based tourism (CBT) as a local human resource, plays an important role in developing the community, developing capacity, having control at the local level and developing the business of local communities, as sustainable livelihoods and poverty alleviation [8], [9]. With the entry of technology, information and communication in the tourism sector and trends in changing consumer behavior that is increasingly mobile, personal, interactive, increasingly digital and more personal - tourism 4.0 - CBT is making efforts to attract tourists to visit their areas, especially millennial tourists. These CBT efforts include collaboration and innovation in order to increase tourist visits.

This study examines the structuration process on CBT collaboration and innovation qualitatively in terms of its contribution to tourism 4.0 towards the development of sustainable tourism. By analyzing the structuration of CBT as a system, it can be explained the ways the system is produced and reproduced in the interactions of agents in CBT, especially in efforts to deal with tourism 4.0. This research seeks to describe and provide interpretative understanding of the dynamics process of CBT by creating change due to the structuration process.

\section{Method}

This research is qualitative by collecting data with literature review in the last five years and field visits to the Tourism Village of Kaki Langit, Mangunan, Bantul, Yogyakarta 
Province, Indonesia. Researchers chose this tourism village because this tourism village has eight concepts that facilitate community activities. This concept is implemented in eight activity groups: Atap Langit, Karya Langit, Rasa Langit, Budaya Langit, Langit Hijau, Langit Ilalang, Langit Terjal, Langit Cerdas. In addition, the Tourism Village of Kaki Langit is located in the Pine Forest tourist area in Mangunan Village, Bantul, Indonesia so that the managers and community of this tourism village often interact with ecotourism groups, Kelompok Sadar Wisata (POKDARWIS), craftmen groups, and tourism voluunteer groups. Researchers take steps, first, researchers review literature review and articles and journals from the internet, researchers add data from books. The results of previous studies from the literature review, researchers compared with the results of empirical research in the Tourism Village of Kaki Langit to reduce the research gap. This analysis is expected to answer the problems examined in this article.

\section{Result and Discussion}

CBT in Mangunan Village, is one of the CBT that dedicates itself to poverty alleviation and sustainability. A sustainable CBT is needed to reduce the negative impact of tourism on the environment and society [1], [8], [9]. The Tourism Village of Kaki Langit has rules and resources for interacting both internally and externally. Social interaction that occurs in the CBT of The Tourism Village of Kaki Langit, as a reflection of the agents that understanding tourism really helps improve their welfare. Initially, their rules have the shape of village treasure, provincial fund, home stay, natural, culinary, cultural potencies tourism potency. Meanwhile, their resources are still colored by the values of traditional traditions. Then the rules and resources change. The discussion of the changes is related to CBT collaboration and innovation below.

\subsection{Collaboration and Innovation from CBT of the Tourism Village}

CBT of The Tourism Village of Kaki Langit began managing tourism industry pioneers or tourism businesses that already exist in the Mangunan Village. In other words, they involve the community in developing tourism Community involvement helps to share the same opportunities, empower the community, promote community solidarity and provide broad benefits to the community [10]. Community involvement was marked by the formation of eight activity groups in the management of tourism villages. From the interview is known that social interaction among agents as group is done routinely in a formal and informal meeting or working group. One of the agents states 'the Tourism Village of Kaki Langit is a region consist of eight Neighborhood Associations, they often meet and keep in touch".

Besides community involvement, CBT of The Tourism Village of Kaki Langit collaborates with many parties as Generasi Pesona Indonesia (Gen-Pi), local government, district government, provincial government, central government, dan academics. This collaboration has three main dimensions as a participation in making decision process, coordination and communication [11]. For example, collaboration with Generasi Pesona Indonesia (Gen-Pi), CBT of The Tourism Village of Kaki Langit asked Gen-Pi to help promote the Skyline Tourism Village since the Digital Market of Kaki Langit was opened. If the Tourism Village of Kaki Langit holds events, it informs Gen-Pi. So Gen-Pi came, broadcasted and promoted it to digital media like Instagram, Twitter and Facebook. 
Collaboration is as a commitment by creating equal participation and managing tensions to reach efficiency. Group flexibility becomes an adaption ability, adjustment and change rapidly in facing challenge and obstacles, commitment among members to develop their group. Commitment created to maintain relationships between organizations has a positive effect on the organization to focus on continuous innovation and relevance to its partners. The innovation of a group or organization arises can begin when the leader of the organization coordinates and organizes the tasks of the members [12]. CBT of the Tourism Village of Kaki Langit innovates because of leadership and collaboration with partners. Management of the Tourism Village of Kaki Langit was found that there is structural leadership and daily leadership. Agent 1 says that there is a daily leader besides leader 1 and leader 2 . The daily leader is leader 2. Leader and daily management are always on the field, so every time they have guests and tourists visits, they will accompany. Agent 2 and 3 say hat daily management is needed for the sustainability for thr tourism. Leader 1 has a role as a leader of coosp of Notowono pine forest so he can't monitor on the field regularly..

Managers of the the Tourism Village of Kaki Langit always follow meetings with the working group, Kelompok Sadar Wisata (POKDARWIS) Mangunan Village and Village Community Group Work, Kelompok Kerja Lembaga Pemberdayaan Masyarakat Desa (KKLPMD) Mangunan Village. The position of POKDARWIS as another institution outside CBT that provides motivation and encouragement to CBT. Whereas KKLPMD as another institution influences CBT operations, performance and resources. Both are organizational environments that are part of the structure of CBT. The results of the meeting (deliberation, decision making) of the manager, KKLPMD and Pokdarwis were distributed to eight working groups in the Tourism of Kaki Langit. The tourism village of Kaki Langit has four important characteristics process to the collaboration, that stated by Kramer, Hoelscher, Nguyen, Day dan Cooper (2017) is those organization have same goals, dependency from members, get some input from the participants and joint decision making [13].

The communication media carried out by the Tourism Village of Kaki Langit, initially the tourism village management and the community were still traditional namely word of mouth (WOM), invitation paper and cell phones. But with the inclusion of the internet in their area, they switched to using whatsapps social media. the Tourism Village of Kaki Langit also made Instagram \#kakilangit_mangunan and websites as a means of promotion and marketing. However, the contents of both are less updated.

\subsection{Adaptive Structuration in Collaboration and Innovation of CBT of the Tourism Village of Kaki Langit}

The social system of the Tourism Village of Kaki Langit such as collaboration, looks relatively stable but also changes over time. The managers and the administrators of the Tourism Village of Kaki Langit have resources and rules that enable and limit the actions of agency interactions (actors) that are reflected in communication in CBT. Resources are material that is owned to control the actions of the group or its members while rules are the proposition that must be done or what problems are good and bad. But it is not possible, the managers of the Tourism Village of Kaki Langit make changes with production and reproduction. Duality structure considers that rules and resources are the medium and the [14]. Poole said that changes to rules and resources depend on appropriation process from group members [15]. The CBT members involved, influenced the group and structured the group. At first, each group of activities managing the working group did not have a coordinator. Through this appropriate process, it produces decisions about each concept working group owned by 
the coordinator to facilitate the implementation of group tasks. Visual illustration of the process of structuring CBT, production and reproduction rules and resources in Figure 1.

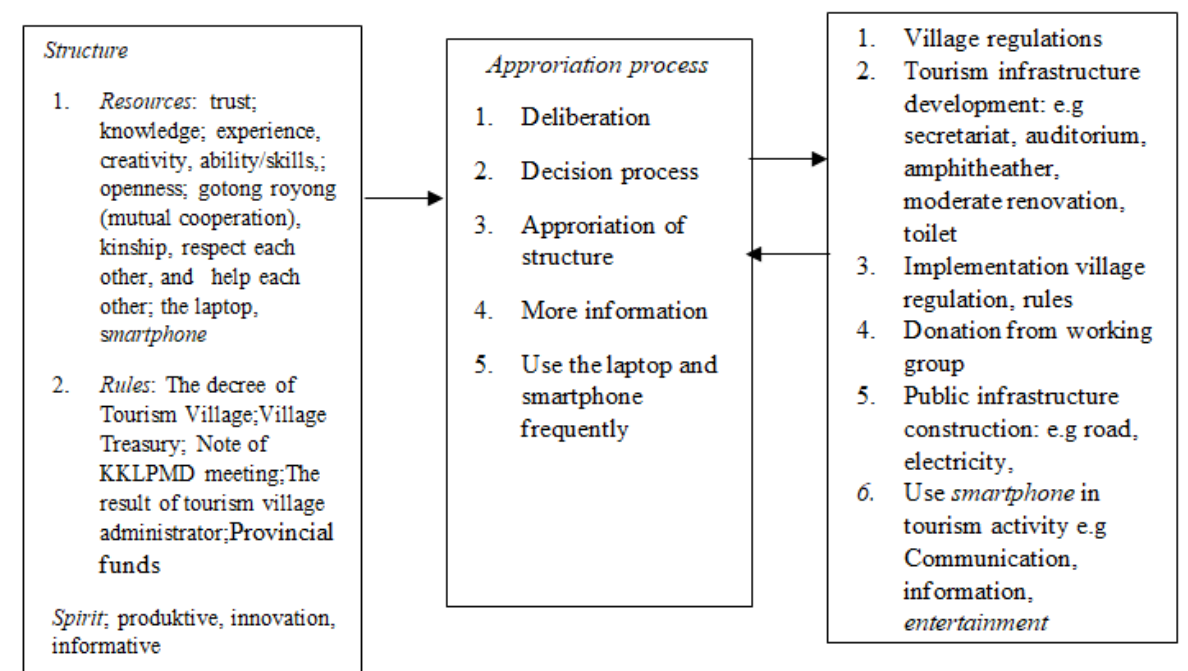

Fig. 1. Structuration process on Community Based Tourism . Adapted from [15]

This structuration process continues to follow CBT members. CBT members are active agents. During the process, structure increases the efficiency but reduces participation. The group leader positively believes when he announces the important of participant not to get trapped into too many details in the last meeting. As described by Pomerol (2013) 'the decision which is taken on the right time is much better than the best decision taken late. [13]. However, this condition, does not obstruct the activities of developing the tourism villages. Although some members of CBT do not show their true abilities. Some members dominate the meeting so the decisions taken are more political than rational. Members are given the freedom to act and have the capacity to make a difference. Rules and resources turned out to be an attraction for tourists visiting the Tourism Village of Kaki Langit. The community is aware of these two things so they are trying to make positive changes while maintaining local wisdom.

\subsection{New Social Structure of Interaction Results}

The agents of the Tourism Village of Kaki Langit strive to carry out their duties in order to realize the satisfaction of the guests / tourists who visit. In the beginning, the structure of the Tourism Village of Kaki Langit did not have a coordinator in eight activity groups and the Chair had a dual role outside the structure of the tourism village. Then, the rules change with the presence of a coordinator and a daily chairman and administrator. This change is a form of appropriation from the management and the community of the Tourism Village of Kaki Langit. Daily agents unconsciously divide their roles and time/ opportunities to visit the secretariat and accompany guests who visit suddenly. The researcher identified that the agent's actions were formed from the results of repeated interactions and carried out as part of efforts to maintain the continuation of the service process of the Tourism Village of Kaki Langit to tourists 
In addition, the manager and the administrators of the Tourism Village of Kaki Langit began to use the internet since wifi entered. Smartphones, and social media began to be used as a medium of communication with family, friends and village tourism management needs. For example the adoption of whatsapps. KKLPMD has whatsapps group emerged for more connections and communication between members. Although it is still informational and not all CBT members can use whatsapps features. The decision making process also still has to be face to face. Then the adoption of Instagram. CBT of the Tourism Village of Kaki Langit uses the Instagram application for promotional media but its existence is still considered lacking and there is no special administrator in charge of updating the Instagram. However, agents still use other features such as e-mail and cell phones to answer questions and submit information requested to guests / tourists to maintain the tourism services of the Tourism Village of Kaki Langit. The choice of these features is because agents are accustomed to doing the same thing when completing work outside managing the tourist village, which requires interaction with the external environment.

The researcher identified that there was agreement between the agents in two directions. The agents sometimes encounter obstacles related to resources. For example, a weak wifi connection, making it difficult to do on line. To overcome this, the agents communicate with developers and other agents who have skills in the IT field. These things can be indicated by the existence of new social structures that are produced and reproduced. At the same time the outcome produced changes or not, which changes into the group's innovation.

\section{CONCLUSION}

This study reveals the structuring of communication in CBT as an examining of CBT collaboration and innovation in Tourism 4.0, so that it can be found out how much the potential for sustainable CBT. CBT of The Tourism Village of Kaki Langit uses rules and resources to meet its goals in developing tourism in the region. Changes in rules and resources have an impact on the behavior of CBT members. CBT of The Tourism Village of Kaki Langit appropriate Tourism 4.0 by conducting communication, social activities, finding information and news with the internet, the use of smartphones and laptops. Thus, this research has contributed to the CBT literature and adaptive structuration theory.

\section{Acknowledgement}

This article is part of empirical study related to Grant Research Program of State non-tax revenue at the national level (Pendapatan Nasional Bukan Pajak /PNPB) 2019 of Universitas Sebelas Maret, Surakarta, Indonesia. This research cannot be accomplished without immense help of tourism players, public figures and administrators of Tourism Village of Kaki Langit, Mangunan Village, Dlingo District, Bantul, Yogyakarta Province.

\section{References}

[1] M. Sunuantari, "Tourism communication in community based tourism in Dieng community, Central Java , Indonesia," Binus Business. Review., vol. 8, no. 2, pp. 149$156,2017$. 
[2] N. Zubaidah, I. Amin, N. Wijayanto, and M. Shamil, "RI Sibuk Kejar Industri 4," www.sindonews.com, 08-Feb-2019.

[3] Karinov, "Revolusi Industri 5.0 ala Jepang: Human-Centered Society," karinov.co.id, 29-Jan-2019. [Online]. Available: https://karinov.co.id/revolusi-industri-5-jepang/.

[4] H. Y. Raharja, "Relevansi pancasila era industry 4.0 dan society 5.0 di pendidikan tinggi vokasi," J. Digit. Educ. Commun. Arts, vol. 2, no. 1, pp. 11-20, 2019.

[5] T. Mazali, "From industry 4.0 to society 4 .0, there and back," AI Soc., vol. 0, no. 0, pp. 1-7, 2017.

[6] "Kementerian Pariwisata RI CEO Message \#62 Tourism 4.0 adalah Millenial Tourism,"www.kemenpar.go.id, 27-Feb-2019.

[7] S. Puspita, "Tourism 4.0 Jadi Tren Pengembangan Pariwisata Dunia," kompas.com, 01Mar-2019.

[8] T. B. Dangi and T. Jamal, "An integrated approach to 'Sustainable Community-Based Tourism ,"' Sustainability, vol. 8, no. 475, pp. 1-32, 2016.

[9] T. Hung and F. Jan, "Can community-based tourism contribute to sustainable development? Evidence from residents ' perceptions of the sustainability," Tourism Management., vol. 70, no. September 2017, pp. 368-380, 2019.

[10] T. Ngo, G. Lohmann, and R. Hales, "Collaborative marketing for the sustainable development of community-based tourism enterprises: voices from the field," Sustainability., pp. 1-20, 2018.

[11] M. Bourgault and J. Daoudi, "Innovation project conducted by distributed teams: The impact of key team characteristics on collaboration," Journal of Innovation and Economics and Management, vol. 1, no. 13, pp. 37-72, 2014.

[12] F. Zach, "Collaboration for Innovation in Tourism Organizations: Leadership Support, Innovation Formality, and Communication," Journal of Hospitality and Tourism Research., vol. XX, no. X, pp. 1-20, 2013.

[13] M. W. Kramer, C. S. Hoelscher, C. Nguyen, E. A. Day, and O. D. Cooper, "Structuration processes in an interagency collaboration: enabling and constraining participation and efficiency," Journal of Applied Communication Research., vol. 45, no. 4, pp. 429-444, 2017.

[14] A. Giddens, The Constitution of Society: Outline of the Theory of Structuration. Cambridge: Polity Press, 1984.

[15] M. S. Poole, "Adaptive Structuration Theory," in A First Look at Communication Theory, 7th ed., E. Griffin, Ed. New York: www.afirstlook.com, 2009. 